\title{
MANAJEMEN KINERJA STAF TATA USAHA DALAM PELAYANAN ADMINISTRASI KESISWAAN DI SMP NEGERI 2 SAMBAS
}

\author{
Oleh: Yusniar ${ }^{1}$
}

\begin{abstract}
Abstrak: Dalam bidang administrasi kesiswaan kualitas pelayan menggambarkan kualitas suatu sekolah. Penelitian tentang dilakukan di SMP Negeri 2 Sambas. Metode yang digunakan adalah pendekatan penelitian kualitatif, jenis penelitian studi kasus, orientasi teoritisnya mengacu pada teori Fenomenologi. Hasil wawancara, pengamatan dan dokumen sekolah terungkap bahwa; perencanaan, pelaksanaan, dan evaluasi kinerja staf tata usaha oleh kepala sekolah di SMP Negeri 2 Sambas sesungguhnya dilakukan untuk menopang kinerja kepala sekolah dalam rangka memaksimalkan pelayanan dibidang administrasi kesiswaan.
\end{abstract}

Kata Kunci: manajemen kinerja, staf tata usaha, pelayanan administrasi kesiswaan.

Abstract : In the field of quality student administration waiter describe the quality of a school . Research on done in SMP Negeri 2 Sambas. The method used is a qualitative research approach, case study, theoretical orientation refers to the theory of phenomenology. Interviews, observation and documents revealed that school ; planning, implementation, and evaluation of the performance of administrative staff by the principal in SMP Negeri 2 Sambas actually done to sustain the performance of principals in order to maximize the field of administration of student services .

Keywords : performance management, administrative staff, student administrative services

\section{Pendahuluan}

Berbagai upaya untuk meningkatkan mutu pendidikan terus dilakukan pemerintah. Menurut Fasli Jalal dalam http://repository.upi.edu/ operator/ upload /sa0151_054033_chapter1.pdf, setidaknya ada empat aspek penting

${ }^{1}$ Guru SMK Negeri 2 Sambas 
yang tengah menjadi program pemerintah dalam upaya peningkatan mutu pendidikan, yaitu aspek kurikulum, tenaga kependidikan, sarana pendidikan, dan kepemimpinan satuan pendidikan

Kenyataannya peningkatan kualitas mutu pendidikan nyaris tidak terdengar melibatkan juga peningkatan kualitas staf tata usaha yang merupakan bagian tenaga kependidikan. Staf tata usaha merupakan aspek penting yang sering kita lupakan peran dan urgensinya. Selama ini kita berkutat pada dua hal yang selalu kita gaungkan, yaitu peningkatan kualitas siswa dan guru, jarang atau boleh dibilang tidak pernah sebuah wacana dilemparkan mengenai peningkatan kualitas staf tata usaha.

Ada 4 (empat) tugas tata usaha yakni; school assistant, clerical assistant, finance assistant dan general assistant. Staf tata usaha bertugas dalam berbagai bidang, baik bekerja sama dengan kepala sekolah dan guru atau mereka bekerja sendiri. Tugas mereka meliputi, membantu proses belajar mengajar, urusan kesiswaan, kepegawaian, peralatan sekolah, urusan infrastruktur sekolah, keuangan, bekerja di laboratorium, perpustakaan dan hubungan masyarakat (Cep Hendri: 2007)

Kegiatan guru dalam melaksanakan proses pembelajaran di sekolah tidak bisa lepas dari peran tata usaha yang membantu operasional sekolah. Fungsi tata usaha merupakan link untuk menjalankan fungsi sekolah. Apabila link tersebut error maka operasional sekolah juga akan mengalami gangguan. Hal ini berkaitan dengan kualitas dari staf tata usaha itu sendiri. Kebanyakan staf tata usaha yang ada sekarang ini adalan lulusan SLTA. Jarang sekali staf tata usaha berasal dari sarjana administrasi dan mereka cenderung dikondisikan untuk bisa mengerjakan apapun.

Kondisi ini jelas mempengaruhi kinerja dan efektifitas staf tata usaha. Sedangkan usaha peningkatan mutu staf tata usaha tidak pernah dilakukan oleh sekolah, hanya sekolah-sekolah tertentu yang mempunyai standar khusus untuk staf tata usaha dan berusaha agar peningkatan kualitas sumber daya manusia tidak hanya fokus kepada guru dan siswa, tetapi juga adanya upaya untuk meningkatkan kualitas staf tata usaha untuk mencapai suatu proses manajemen dan pengaturan administrasi yang maksimal di sekolah.

Pencapaian sebagai Sekolah Standar Nasional pertama di Kecamatan Sambas oleh SMP Negeri 2 Sambas merupakan suatu yang istimewa. Dengan 5 orang staf tata usaha yang melayani sekitar 640 siswa dan 36 guru dan mereka mampu memberikan kontribusi pada sekolah dalam mengukir prestasi. Pola kepemimpinan kepala sekolah, sarana dan prasarana sekolah serta kemampuan administrasi dari staf tata usaha sangat menentukan pencapaian ini. Walaupun dengan sarana dan kemampuan yang minim, tetapi mereka 
sudah memperoleh pencapaian yang masih belum didapatkan oleh sekolah lain di Kabupaten Sambas.

Kita tidak hanya menyorot keberhasilan dari sebuah kinerja tata usaha, tetapi kita akan mencoba mengeloborasi sebuah bagian dari sekolah yang menjalankan fungsi administrasi dengan perbandingan 1 (satu) orang staf tata usaha melayani lebih dari 135 siswa dan guru di sekolah tersebut. Perbandingan yang mencolok antara yang dilayani dan staf tata usaha tidak menjadi penghalang, mereka malah dapat memberikan kontribusi mereka dalam pengembangan dan pencitraan sekolah, padahah kualifikasi mereka ratarata tamatan SLTA pada awalnya tidak mempunyai dasar ilmu administrasi.

Atas keberhasilan staf tata usaha SMP Negeri 2 Sambas dalam memberikan pelayanan administrasi kepada seluruh warga sekolah dan orangorang yang berkepentingan dengan administrasi sekolah ini menarik peneliti untuk mengungkap keberhasilan tersebut.

Fokus penelitian diarahkan pada manajemen kinerja staf tata usaha dalam pelayanan administrasi kesiswaan di SMP Negeri 2 Sambas. Beberapa aspek yang akan dikaji terkait fokus penelitian yaitu " bagaimana perencanaan, pelaksanaan, dan evaluasi program kinerja staf tata usaha oleh kepala sekolah dalam pembinaan staf tata usaha memberikan pelayanan administrasi kesiswaan di SMP Negeri 2 Sambas serta apa faktor pendukung dan penghambat program kinerja staf tata usaha oleh kepala sekolah dalam pembinaan staf tata usaha memberikan pelayanan administrasi kesiswaan di SMP Negeri 2 Sambas?

Tujuan utama penelitian ini adalah untuk mengungkapkan Manajemen Kinerja Staf Tata Usaha dalam Pelayanan Administrasi Kesiswaan (Studi Kasus Pembinaan Staf Tata Usaha Oleh Kepala Sekolah di SMP Negeri 2 Sambas).

\section{Manajemen}

Manajemen adalah melakukan pengelolaan sumber daya yang dimiliki oleh sekolah/organisasi yang diantaranya adalah manusia, uang, metode, material, mesin, dan pemasaran yang dilakukan dengan sistematis dalam suatu proses (Rohiat, 2010:14).

Mulyono (2008:18) berpendapat bahwa manajemen adalah sebuah proses yang khas dari perencanaan, pengorganisasian, penggerakan dan pengawasan serta evaluasi yang dilakukan pihak pengelola organisasi untuk mencapai tujuan bersama dengan memberdayakan sumber daya manusia dan sumber daya lainnya. Stephen P. Robbins ( 2008.5) sendiri menyingkatnya menjadi empat yaitu perencanaan, pengorganisasian, kepemimpinan dan pengendalian. 
Kepala sekolah sebagai seorang manajer pada hakikatnya adalah seorang perencana, organisator, pemimpin dan seorang pengendali. Keberadaan manajer pada suatu organisasi sangat diperlukan, sebab organisasi sebagai alat mencapai tujuan organisasi di mana di dalamnya berkembang berbagai macam pengetahuan, serta organisasi yang menjadi tempat untuk membina dan mengembangkan karir-karir sumber daya manusia, memerlukan manajer yang mampu untuk merencanakan, mengorganisasikan, memimpin dan mengendalikan agar organisasi dapat mencapai tujuan yang telah ditetapkan.

Menurut Hikmat ( 2011:47 ) manajer adalah pimpinan atau pemimpin suatu organisasi. Manajer memegang otoritas yang menentukan perkembangan suatu organisasi. Kedudukannya sangat strategis karena berhubungan secara langsung dengan pegnambilan keputusan dan kebijaksanaan yang ditetapkan untuk dilaksanakan secara operasional oleh seluruh bawahannya.

Sedangkan menurut Husaini Usman ( 2011:3), manajer adalah orang yang melakukan kegiatan manajemen. Manusia sebagai manajer dimanapun berada tidak terlepas dari wadah untuk melakukan kegiatan.

Dengan demikian istilah manajer adalah siapa saja yang bertanggung jawab untuk melaksanakan aktivitas utama dalam sebuah manajemen. Aktivitas utama dibagi menjadi empat bagian, yang memang merupakan tugastugas pokok seorang manajer, yakni: merencanakan, mengorganisasikan, memimpin dan mengendalikan.

Dari pendapat di atas dapat disimpulkan bahwa manajer adalah orang yang mempunyai tanggung jawab atas bawahan sumber daya organisasi yang mana ia dapat mengkoordinasikan aktifitas organisasi dalam rangka mencapai tujuan. Dikemukakan pula bahwa sebagai kepala administrasi, kepala sekolah bertugas untuk membangun manajemen sekolah serta bertanggungjawab dalam pelaksanaan keputusan manajemen dan kebijakan sekolah.

\section{Kepala Sekolah sebagai Manajer}

Di era kemandirian sekolah dan era Manajemen Berbasis Sekolah (MBS) sekarang ini, kiranya pemahaman, pendalaman dan aplikasi konsepkonsep ilmu manajemen yang telah banyak dikembangkan oleh para pemikir di bidang bisnis perlu mendapatkan perhatian para pimpinan sekolah untuk memanajemeni sekolah-sekolah yang mereka pimpin di masa kini. Kesempatan untuk mengembangkan sebuah sekolah hingga menjadi sebuah sekolah efektif kiranya membutuhkan kreativitas kepemimpinan yang memadai.

Menurut Lipham dan Trankin, dalam Dadi Permadi ( 2009:25) menyatakan bahwa "Principals must understand and develop skills in the implementation of change if school are to become more efective" (kepala 
sekolah harus memahami dan mengembangkan keterampilannya dalam melaksanakan perubahan jika sekolah menjadi efektif).

Pidarta dalam Mulyono ( 2008:151) mengemukakan tiga macam keterampilan yang harus dimiliki oleh kepala sekolah untuk menyukseskan kepemimpinannya. Pertama keterampilan konseptual, yaitu keterampilan untuk memahami dan mengoperasikan organisasi. Kedua, keterampilan manusiawi, yaitu keterampilan untuk bekerja sama, memotivasi dan memimpin. Ketiga, keterampilan teknik, yaitu keterampilan dalam menggunakan pengetahuan, metode, teknik serta perlengkapan untuk menyelesaikan tugas tertentu.

\section{Perencanaan dalam Manajemen Kinerja}

Perencanaan menurut Mulyono (2008.25-26) mengandung arti: pertama, manajer memikirkan dengan matang terlebih dahulu sasaran (tujuan) dan tindakan berdasarkan beberapa metode, rencana, atau logika dan bukan berdasarkan perasaan. Kedua, rencana mengarahkan tujuan organisasi dan menetapkan prosedur terbaik untuk mencapainya. Ketiga, rencana merupakan pedoman untuk: (a) organisasi memperoleh dan menggunakan sumber daya yang diperlukan untuk mencapai tujuan, (b) anggota organisasi melaksanakan aktivitas yang konsisten dengan tujuan dan prosedur yang sudah ditetapkan, dan (c) memonitor dan mengukur kemajuan untuk mencapai tujuan, sehingga tindakan korektif dapat diambil bila kemajuan tidak memuaskan.

Handoko (2011:53) berpendapat bahwa perencanaan sumber daya manusia merupakan serangkaian kegiatan yang dilakukan untuk mengantisipasi perminta an-permintaan bisnis dan lingkungan pada organisasi di waktu yang akan datang dan untuk memenuhi kebutuhan-kebutuhan tenaga kerja yang ditimbulkan oleh kondisi-kondisi tersebut.

Mulyono (2008.26) berpendapat bahwa perencanaan yang baik hendaknya berdasarkan; a) asas pencapaian tujuan, b) asas dukungan data yang akurat, c) asas menyeluruh (komprehenshif dan integrated), dan d) asas praktis.

\section{Kinerja Staf Tata Usaha}

Menurut Irham Fahmi (2010:2) kinerja adalah hasil yang diperoleh oleh suatu organisasi baik organisasi tersebut bersifat profit oriented dan non profit oriented yang dihasilkan selama satu periode waktu.

Uhar Suharsaputra (2010:144) mengatakan bahwa kinerja atau performance berarti tindakan menampilkan atau melaksanakan suatu kegiatan. Kinerja merupakan suatu kemampuan kerja atau prestasi kerja yang diperlihatkan oleh seorang pegawai untuk memperoleh hasil kerja yang optimal. Kinerja seseorang akan tampak pada situasi dan kondisi kerja seharihari. Aktivitas-aktivitas yang dilakukan oleh seseorang dengan melaksanakan 
pekerjaannya menggambarkan bagaimana ia berusaha mencapai tujuan yang telah ditetapkan.

Kinerja diartikan prestasi kerja atau pelaksanaan kerja atau hasil unjuk kerja. Kinerja adalah hasil dari suatu proses yang dilakukan manusia. Kinerja merupakan suatu wujud perilaku seseorang atau organisasi dengan orientasi prestasi. ( Dirjen PMPTK Depdiknas, 2008: 20 )

\section{Administrasi Kesiswaan}

Administrasi kesiswaan adalah usaha dan kegiatan yang meliputi pengaturan tentang administrasi yang berkaitan dengan siswa dalam upaya mengembangkan potensi siswa. Administrasi bidang kesiswaan mencakup ruang lingkup pencatatan data dan pelaporan. Keduanya sama penting dan saling berkaitan, dan untuk itu perlu disediakan format-format untuk menunjang pencatatan dan pelaporan tersebut (http://id.shvoong.com/socialsciences/ education/2024168-administrasi-siswa/\#ixzz3qF Nwz71wUC).

\section{Metodologi Penelitian}

Dilihat dari latar belakang alamiah dan peneliti merupakan instrumen utama meletakkan penelitian ini sebagai penelitian kualitatif dan jenis penelitian studi kasus. Pendekatan eksploratif yang bersifat mendalam dengan menganalisis apa yang sebenarnya terjadi di balik fakta atau kasus. "Peneliti tidak akan memandang bahwa sesuatu itu sudah memang sedemikian keadaannya (Moleong 2011.11)

Dengan demikian orientasi teoritisnya mengacu pada teori Fenomenologi, sebagaimana dikatakan oleh Moleong (2011.14) bahwa "pada dasarnya landasan teoritis dari penelitian kualitatif bertumpu secara mendasar pada fenomenologi". Fenomenologi pada dasarnya berpandangan bahwa apa yang tampak dipermukaan, termasuk pola perilaku manusia sehari-hari hanyalah sesuatu gejala atau fenomena dari apa yang tersembunyi di "kepala" sang pelaku. Realitas itu sesungguhnya bersifat subyektif dan maknawi. Ia bergantung pada persepsi, pemahaman, pengertian, dan anggapan-anggapan seseorang ( Bungin. (Ed). 2008.9). Proses analisis data lebih difokuskan selama proses di lapangan bersamaan dengan pengumpulan data (Sugiyono,2008:90).

\section{Manfaat Penelitian}

Manfaat teoritis dari penelitian ini adalah untuk mengembangkan ilmu administrasi pendidikan terutama dari aspek pemberdayaan pengembangan tenaga kependidikan, hubungan antar komponen pendidikan dalam institusi 
pendidikan, pengembangan pelayanan administrasi kesiswaan yang diyakini memiliki kontribusi dalam peningkatan mutu pendidikan secara keseluruhan.

Sedangkan manfaat praktisnya diharapkan akan berkontribusi besar bagi kepala sekolah untuk merencanakan program kinerja staf tata usaha oleh kepala sekolah dalam pembinaan staf tata usaha memberikan pelayanan administrasi kesiswaan di sekolah.

\section{Pembahasan Tmuan Penelitian}

Perencanaan program kerja tata usaha di SMP Negeri 2 Sambas dilakukan dalam rangka meningkatkan pelayanaan kepada siswa, guru, masyarakat, dan pelanggan yang memerlukan, khususnya masalah administrasi kesiswaan. Karena diyakini bahwa administrasi di sekolah menggambarkan secara langsung kualitas dan mutu dari suatu sekolah.

Temuan di atas sesuai dengan pendapat beberapa para ahli antara lain adalah George Milkovich dan Paul C. Nystrom dalam Yuwanita dan Hutami (2007/2008.3) mengatakan bahwa perencanaan sumber daya manusia adalah proses peramalan, pengembangan, pengimplementasian dan pengontrolan yang menjamin perusahaan mempunyai kesesuaian jumlah pegawai, penempatan pegawai secara benar, waktu yang tepat, yang secara otomatis lebih bermanfaat.

Selanjutnya Handoko (2011:53) menyimpulkan bahwa perencanaan sumber daya manusia merupakan serangkaian kegiatan yang dilakukan untuk mengantisipasi permintaan-permintaan lingkungan organisasi di waktu yang akan datang dan untuk memenuhi kebutuhan-kebutuhan tenaga kerja yang ditimbulkan oleh kondisi-kondisi tersebut.

Perencanaan merupakan proses terpenting dari semua fungsi manajemen karena tanpa perencanaan fungsi-fungsi lain pengorganisasian, pengarahan, dan pengontrolan tak akan dapat berjalan.

Pelaksanaa pembinaan kinerja staf tata usaha oleh Kepala Sekolah di SMP Negeri 2 Sambas dilakukan dengan 2 (dua) metode, internal dimana Kepala Sekolah secara langsung melakukan dan memberikan pembinaan kepada staf tata usaha yang dinilai masih kurang efektif dalam melakukan tugas dan pekerjaan mereka. Pembinaan yang dilakukan biasanya dilakukan dengan memberikan teguran dan pemberian contoh atau cara yang terbaik atau yang paling effesien dalam melakukan suatu tugas.

Sementara pelaksanaan pembinaan dengan cara atau metode eksternal dilakukan dengan mengutus atau memberikan kesempatan kepada staf untuk mengikuti pelatihan dalam rangka menerima informasi baru yang nantinya berguna dalam tugas yang akan dikerjakan di sekolah. 
Senada dengan temuan di atas, Rivai dan Sagala, Hariandja, Rivai dan Basri dalam Rumbayan (2011:9-12) mengemukakan tentang metode atau teknik penilaian kinerja karyawan sebagi berikut:

a) Metode penilaian berorientasi masa lalu, dimana penilaian perilaku kerja dilakukan berdasarkan kinerja masa lalu. Melalui hasil penilaian tersebut dapat dilakukan usaha untuk mengubah perilaku kerja atau pengembangan pegawai. Beberapa metode ini terdiri dari rating scale ,checklist, critical incident technique, skala penilaian berjangkarkan perilaku, observasi dan tes unjuk kerja dan metode perbandingan kelompok atau pendekatan evaluasi komparatif.

b) Metode penilaian berorientasi masa depan, yaitu penilaian akan potensi seorang pegawai untuk melakukan pekerjaan pada masa yang akan datang meliputi penilaian diri sendiri, management by objective, penilaian secara psikologis dan assessment centre.

Pengembangan merupakan peningkatan keterampilan melalui pelatihan yang perlu untuk prestasi kerja yang tepat. Kegiatan ini sangat penting mengingat banyaknya perubahan-perubahann teknologi, reorganisasi pekerjaan, tugas manajemen yang semakin rumit dan makin kompleknya tugastugas manajer. Langkah bijak yang dilakukan oleh kepla sekolah SMP Negeri 2 Sambas ini patut di apreasiasi oleh warga sekolah terutama staf tata usaha selaku sasaran pembinaan.

Dalam memberikan pelayanan bidang administrasi kesiswaan yang dilakukan oleh staf tata usaha, kepala sekolah mengevaluasi kinerja staf tata usaha berdasarkan standar waktu yaitu waktu penyelesaian tugas dan hasil kerja pelayanan administrasi kesiswaan. Kepala sekolah melakukan pembinaan yang bersifat internal untuk meningkatkan kinerja staf tata usaha.

Penilaian kinerja pada dasarnya merupakan faktor kunci guna mengembangkan suatu organisasi secara efektif dan efisien, karena adanya kebijakan atau program yang lebih baik atas sumber daya manusia yang ada dalam organisasi, yang sangat bermanfaat bagi dinamika pertumbuhan organisasi secara keseluruhan. Melalui penilaian tersebut maka dapat diketahui kondisi sebenarnya tentang bagaimana kinerja karyawan.

Yuwanita dan Hutami ( 2007/2008.3) mengutip pendapat para ahli antara lain: Bernardin dan Russel mengatakan bahwa penilaian kinerja adalah cara mengukur konstribusi individu ( karyawan) kepada organisasi tempat mereka bekerja. Selanjutnya Cascio menegaskan bahwa penilaian kinerja adalah sebuah gambaran atau deskripsi yang sistematis tentang kekuatan dan kelemahan yang terkait dari seseorang atau suatu kelompok. 
Sejalan dengan temuan diatas Rivai dan Sagala (2011) menyimpulkan bahwa penilaian kinerja merupakan suatu sistem formal dan terstruktur yang digunakan untuk menilai dan mempengaruhi sifat-sifat yang berkaitan dengan pekerjaan, perilaku dan hasil kerja karyawan termasuk tingkat kehadiran.

Dengan demikian konsep evaluasi program kinerja staf tata usaha yang dilakukan oleh kepala sekolah SMP Negeri 2 Sambas dalam rangka pembinaan staf tata usaha merupakan suatu langkah strategis untuk menopang kinerja sekolah menuju sekolah bermutu secara keseluruhan.

Faktor pendukung pembinaan kinerja staf tata usaha yang meningkatkan pelayanan administrasi kesiswaan yaitu: saling mendukung dalam melaksanakan tugas administrasi kesiswaan serta kesediaan menerima pembinaan yang dilakukan olah Kepala Sekolah.

Bila dianalisa hasil temuan terkait faktor pendukung dalam pembinaan staf tata usaha di SMP Negeri 2 Sambas diakui faktor kebersamaan, tanggungjawab dan mau menerima kelemahan yang ada merupaka modal kerja yang mereka miliki selama ini. Faktor-faktor tersebut oleh Mangkunegara disebut sebagai faktor motivasi. Sebagai mana pendapat beliau berikut ini.

Faktor yang mempengaruhi kinerja antara lain :

a. Faktor kemampuan. Secara psikologis kemampuan (ability) pegawai terdiri dari kemampuan potensi (IQ) dan kemampuan realita (pendidikan). Oleh karena itu pegawai perlu ditempatkan pada pekerjaan yang sesuai dengan keahlihannya.

b. Faktor motivasi. Motivasi terbentuk dari sikap (attiude) seorang pegawai dalam menghadapi situasi (situasion) kerja. Motivasi merupakan kondisi yang menggerakkan diri pegawai terarah untuk mencapai tujuan kerja. Sikap mental merupakan kondisi mental yang mendorong seseorang untuk berusaha mencapai potensi kerja secara maksimal.

Faktor-faktor pendukung yang dimiliki ( kebersamaan, tanggungjawab dan mau menerima kelemahan yang ada ) belum cukup untuk bekal melaksanakan pekerjaan bila kita kaitkan dengan intensitas pekerjaan ketataushaan pada masa yang akan datang yang diprediksi semakin kompleks dan rumit.

Faktor-fakor penghambat berupa rendahnya kualifikasi pendidikan yang dimiliki oleh staf tata usaha SMP Negeri 2 Sambas sebenar tidak begitu besar pengaruhnya terhadap hasil kerja. Karena sebagian besar personil tersebut sudah lama dan berpengalaman bekerja ( staf tata usaha seneior) di SMP Negeri 2 Sambas. Masalahnya adalah bila staf tata usaha kurang inisiatif dan kreatif dalam melaksanakan tugas maka akan menghambat kinerja kepala sekolah secara keseluruhan. 
Staf tata usaha kurang inisiatif dan kreatif dalam melaksanakan tugas oleh Gibson dinyatakan sebagai faktor individu sebagai yang ditulisnya berikut ini.

"Ada 3 faktor yang berpengaruh terhadap kinerja : (1) faktor individu: kemampuan, ketrampilan, latar belakang keluarga, pengalaman kerja, tingkat sosial dan demografi seseorang, (2) faktor psikologis : persepsi, peran, sikap, kepribadian, motivasi dan kepuasan kerja, (3) faktor organisasi : struktur organisasi, desain pekerjaan, kepemimpinan, sistem penghargaan (reward system)."

\section{Penutup}

Manajemen kinerja staf tata usaha dalam pelayanan administrasi kesiswaan merupakan pemberdayaan staf tata usaha yang dilakukan oleh kepala sekolah di SMP Negeri 2 Sambas.

Kegiatan tersebut diawali dari adanya perencanaan, pelaksanaan dan evaluasi program kinerja staf tata usaha oleh kepala sekolah. Dalam memberikan pelayanan administrasi kesiswaan di SMP Negeri 2 Sambas standar atau ukuran yang dijadikan indikator adalah waktu penyelesaian dan kualitas hasil pelayanan administrasi.

Faktor pendukung program kinerja staf tata usaha oleh kepal sekolah dalam pembinaan staf tata usaha memberikan pelayanan administrasi kesiswaan di SMP Negeri 2 Sambas adalah adanya saling mendukung dalam bertugas dan menerima dengan baik pembinaan kinerja staf tata usaha yang dilakukan olah kepala sekolah.

Faktor penghambatnya adalah adalah kualifikasi pendidikan rendah, staf tata usaha kurang inisiatif dan kreatif dalam melaksanakan tugas, dan kurang seriusnya Pemerintah Daerah dan Pusat memperhatikan peningkatan kinerja staf tata usaha sekolah.

Rekomendasi dari penulis, agar kepala sekolah menerapkan manajemen partisipatif dalam rangka membuat perencanaan dan pelaksanaan program staf tata usaha dengan lebih intensif menjalin hubungan harmonis dengan orangtua siswa dan memberdayakan bagian humas serta pengurus komite sekolah dan perguruan tinggi yang ada di daerah. Hal ini dimaksudkan untuk meringankan beban kerja kepala sekolah.

khusus kepada staf tata usaha bahwa untuk meningkatkan kompetensi diri yang menopang kualitas kinerja jangan hanya menunggu tapi juga berusaha sendiri untuk mengembangkan diri. Jika ini dilakukan oleh staf tata usaha, selain meringankan beban sekolah juga berdampak terhadap kualitas kompetensi yang mereka miliki yang selanjutkan akan mempermudah mereka dalam melaksanakan pekerjaan ketatausahaan di manapun mereka bekerja. 


\section{Pustaka}

Bungin,Burhan (Ed). 2008. Analisis Data Penelitian Kualitatif.Pemahaman Filosofis dan Metodologis ke Arah Penguasaan Model Aplikasi. Jakarta: Rajawali Press.

Dirjen PMPTK.2008. Penilaian Kinerja Guru.Jakarta: Direktorat Tenaga Kependidikan

Fahmi, Irham. 2010. Manajemen Kinerja Teori dan Aplikasi. Bandung: CV Alfabeta

Gibson,J.L.,Ivancevich,J.M.,Donnelly, Jr., (tidak ada tahun). Organization. Perilaku, Struktur. proses.( Jilid I). Terjemahan oleh Adriani.N.Jakarta: Binarupa Aksara Publisher.

Handoko,T.Hani.2011. Manajemen Sumber Daya Manusia. (Edisi kedua) Yogjakarta: BPFE

Hendri, Cep. 2007. Makalah: Peningkatan Mutu Pegawai Tata Usaha Sekolah Dalam upaya menujang kualitas Pendidikan di Sekolah, (Online), ( http://server.

smanela.sch.id/kumpulan_materi/peraturan_pendidikan/peningkatan $\% 20$ mutu\%20pegawaiTU.pdf. diakses 26-5-2012)

Hikmat. 2011.Manajemen Pendidikan.Bandung: CV Pustaka Setia

http://id.shvoong.com/ social- sciences /education/2024168 administrasi siswal ixzz3qF Nwz7 1wUC Diakses tanggal 12 Oktober 2011

http://repository.upi.edu/operator/upload/s_a0151054033chapter1.pdf akses15$5-2012$

Moleong.Lexy, 2011.Metodologi Penelitian Kualitatif. Bandung: Remaja Rosdakarya Bandung

Mulyono. 2008. Manajemen Administrasi \& Organisasi Pendidikan. Yogjakarta: Ar-Ruzz Media Groups.

Permadi, Dadi. 2009. Kepemimpinan Mandiri ( Profesional) Kepala Sekolah. Bandung . Sarana Panca Karya Nusa

Rivai,V dan Sagala,E,J. 2011. Manajemen Sumber Daya Manusia untuk Perusahaan; Dari Teori ke Praktik. Jakarta. PT.Raja Grafindo Persada.

Robbins,Stephen P. \& Judge,Timothy A. 2008. Perilaku Organisasi. Buku I. Edisi 12. Jakarta: Salemba Empat.

Rohiat. 2010. Manajemen Sekolah. Teori dasar dan Praktik. Bandung: PT.Refika Aditama.

Rumbayan, J.M. 2011. Hubungan Penilaian Kinerja dengan Komitmen Karyawan Rumah Sakit Umum (RSU) Sentosa Bekasi Timur. Skripsi.Departemen Manajemen. Fakultas Ekonomi dan Manajemen IPB 
(Online), (http:// repository.ipb.ac.id/bitstream/ handle/123456789/ 52013/H11jmr.pdf?sequence=1Diakses 27 Mei 2012)

Suharsaputra,Uhar.2010. Administrasi Pendidikan. Bandung: PT. Refika Aditama.

Usman, Husaini.2011. Manajemen Teori, Praktik, dan Riset Pendidikan.Edisi ke-3. Jakarta: Bumi Aksara.

Yuwanita,M dan Hutami,L,P.2007/2008. Perilaku Organisasi. Penilaian Kinerja Karyawan.Jakarta.STIE. 